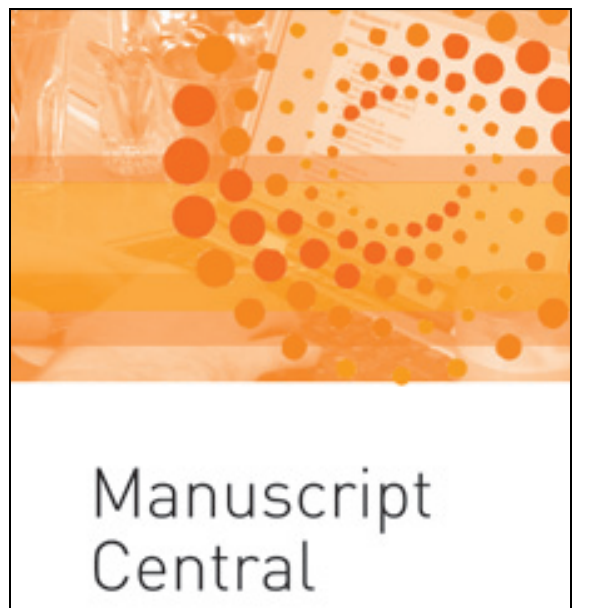

Manuscript Central er et system for levering av manuskripter på Internett http://mc.manuscriptcentral.com/tidsskriftet

\section{Manuscript Central er et redaksjonelt standardsystem brukt av $\mathbf{2} \mathbf{8 0 0}$ tidsskrifter med over 12 millioner registrerte brukere.}

\section{Hvordan komme i gang? \\ Logg deg på http://mc.manuscriptcentral. com/tidsskriftet}

\section{Da får du tilsendt bruker-} navn og passord på e-post. Dersom du allerede er registrert, men har glemt passordet ditt, skriv e-postadressen din inn under Password Help.

\section{Trenger du hjelp?}

Ta kontakt med redaksjonen på telefon 23109050 eller e-post tidsskriftet@legeforeningen.no.

Det finnes også hjelp å få via innloggingssiden i Manuscript Central. Her finner du lenker til brukerveiledning [User Tutorialsl og ofte stilte spørsmål [Get help now].

Tidsskrift for Den norske legeforening

\title{
Om kanel og kanyle
}

I Tidsskriftet nr. 3/2009 skriver Leiv M. Hove i en leder om «kannelerte skruer» (1). Jeg stusset litt over ordbruken og ønsker å komme med en liten kommentar.

Vi forstår vel alle at det som menes, er en skrue som er gjennomhullet for å kunne tres over en ledepinne. På engelsk betegnes slike skruer som «cannulated» og det er mulig at forfatteren har fornorsket dette til «kannelerte». «Cannula» blir imidlertid oversatt til kanyle på norsk. Ordet kanyle er avledet av det latinske «canna» som betyr rør, eller lite rør. Definisjonen på en kanyle er ifølge Bokmålsordboka «1. Rørformet instrument (del) til å føre væske eller luft inn i eller ut av kroppen, eller 2. Nål på injeksjonssprøyte.»

Ordet kannelere, som er beslektet med kanel, brukes derimot om det å lage kannelyre. Kannelyre er en beskrivelse for loddrett rifling på søyler. Dermed må vi vel kunne si at det blir feil å bruke uttrykket «kannelerte» skruer, og jeg vil foreslå at vi på norsk bruker uttrykket «kanylerte» om slike skruer.

\section{Eugen Eide}

eugen.eide@stolav.no

Ortopedisk avdeling

St. Olavs hospital

7006 Trondheim

\section{Litteratur}

1. Hove LM. Håndrotsbrudd - på tide med ny praksis! Tidsskr Nor Legeforen 2009; 129: 176

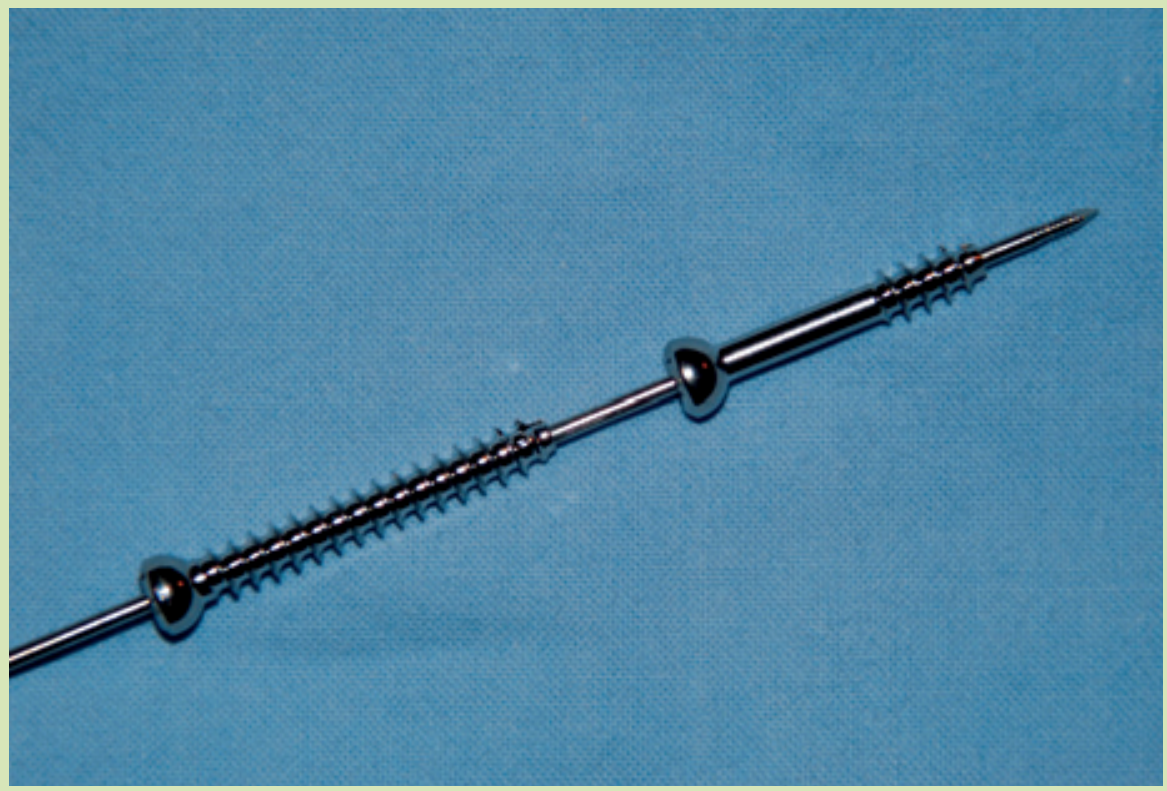

\section{R. Ødegaard svarer:}

I sin leder brukte Leiv M. Hove betegnelsen «kannulerte» skruer. Det ble feilaktig rettet i redaksjonen til «kannelerte» skruer. Vi beklager dette. Det finnes kannelerte skruer, men det var altså ikke den typen det dreide seg om i dette tilfellet.

«Kannulere» er en direkteoversettelse av det engelske «cannulate». Ordet står ikke oppført i norske generelle eller medisinske ordbøker. Når substantivet «cannula» er kanyle på norsk, er det naturlig at verbet «cannulate» blir kanylere på norsk. Dette verbet finner vi i Bokmålsordboka, som Eugen Eide anfører. Det er også oppført i Kunnskapsforlagets medisinske ordbok, med definisjonen: føre inn en kanyle (1). Ord kan ha flere enn én betydning, som i dette tilfellet: å lage som en kanyle/få til å likne på en kanyle. Adjektivet kanylert kanyleliknende/laget som en kanyle - må da kunne fungere godt som beskrivende ledd i uttrykket kanylerte skruer.

\section{Raida Ødegaard}

raida.oedegaard@legeforeningen.no Tidsskriftet

\footnotetext{
Litteratur

1. Nylenna M. Medisinsk ordbok. 6. utg. Oslo: Kunnskapsforlaget, 2004.
} 